\title{
A Case Study: Using The Dupont Approach For Formulating Managerial Decisions
}

\author{
Susan Wright, State University of New York at Oswego, USA
}

\begin{abstract}
This case introduces a unique approach to financial statement analysis that centers on managerial decision-making as the locus for student analysis. Rather than grouping ratios into traditional categories, such as liquidity, asset efficiency, profitability, insolvency and market ratios, ratios are grouped into operating, investing and financing decision-making areas. Students deepen their understanding of a firm's strengths and weaknesses through a process of "drilling-down" into the three decision-making domains. The analysis begins with an examination of ROE using the Dupont analysis which provides a useful framework for focusing on the three core managerial decision making activities. The case is constructed using real world information extracted from $10 \mathrm{~K}$ reports and from recent company announcements. It can be used at the undergraduate (400) or graduate level. It is most suitable for a course in Financial Statement Analysis, or a course in Corporate Financial Management/Corporate Finance. The basics of financial statement analysis are necessary to successfully navigate the case.
\end{abstract}

Keywords: Financial Statement Analysis, Levered Recapitalizations, Wealth Maximization, Critical Thinking Skills

\section{CURRENT SITUATION}

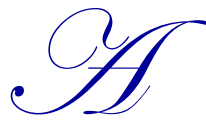

s a junior financial analyst at a large pension fund investment firm, you are responsible for providing investment recommendations related to equity positions appropriate for your client base. One of the core industries you are tracking is biotechnology. The senior investment manager has asked you to prepare an analysis of Biogen's return on equity statistic over the last five years. Additionally, you've been asked to identify trends that are relevant for projecting future growth that are related to managerial decision making regarding core operating, investing and financing activities. The senior project manager will incorporate your analysis in developing future recommendations for holdings in Biogen, Inc.

\section{COMPANY BACKGROUND}

Biogen, Inc. is a public company trading under the symbol BIIB on the NASDAQ stock exchange. The company is a global biopharmaceutical firm that develops treatment-therapies for neurodegenerative diseases (MS), hematologic conditions and autoimmune disorders. It also develops, in collaboration with Genetech, Inc., treatment therapies for non-Hodgkin's lymphomas, certain types of lymphocytic leukemia, and other conditions.

Biogen, Inc.'s stock performance over the last five years has been remarkable. Holding period returns from January 2011 to December 2015 averaged over 350\%. However, recent stock performance has faltered. The stock reached a record high in March of 2015 at $\$ 475$ per share. Since that time, it has been steadily declining. At year-end 2015, the stock was trading around $\$ 306$ per share. During the first quarter of 2016, the stock traded as low as $\$ 245$ per share.

Key developments during late 2015 and early 2016 included a corporate restructuring that involved an $11 \%$ workforce reduction and a leveraged recapitalization program. Biogen, Inc. discontinued several failed product pipelines and at approximately the same time, two top-level executives resigned from the firm. Biogen executed a levered recapitalization for the purpose of providing compensation benefits to employees. The company repurchased shares valued at $\$ 5$ billion. The repurchase was funded through the issuance of $\$ 6$ billion in new senior unsecured debt. Further information regarding these announcements can be found at http://media.biogen.com/. 
Tables $1-3$ include the consolidated financial statements and supplemental data, collected from the company's annual $10 \mathrm{~K}$ reports for each year of the analysis. These reports can be found at https://www.biogen.com/en_us/ investors.html.

Table 1. Biogen Inc. and Subsidiaries Consolidated Statements of Income (in millions)

\begin{tabular}{|c|c|c|c|c|c|}
\hline & \multicolumn{5}{|c|}{ For the year ended December 31} \\
\hline & 2015 & 2014 & 2013 & 2012 & 2011 \\
\hline \multicolumn{6}{|l|}{ Revenues } \\
\hline Product, net & $9,188.5$ & $8,203.4$ & $5,542.3$ & $4,166.1$ & $3,836.1$ \\
\hline Unconsolidated joint business & $1,339.2$ & $1,195.4$ & $1,126.0$ & $1,137.9$ & 996.6 \\
\hline Other & 236.1 & 304.5 & 263.9 & 212.5 & 215.9 \\
\hline Total Revenues & $10,763.8$ & $9,703.3$ & $6,932.2$ & $5,516.5$ & $5,048.6$ \\
\hline \multicolumn{6}{|l|}{ Cost and Expenses: } \\
\hline Cost of sales, exc. Amortization & $1,240.4$ & $1,171.0$ & 857.7 & 545.5 & 466.8 \\
\hline $\mathrm{R} \& \mathrm{D}$ & $2,012.8$ & $1,893.4$ & $1,444.1$ & $1,334.9$ & $1,219.6$ \\
\hline SG\&A & $2,113.1$ & $2,232.3$ & $1,712.1$ & $1,277.5$ & $1,056.1$ \\
\hline Amortization of intangibles & 382.6 & 489.8 & 342.9 & 202.2 & 208.6 \\
\hline Restructuring charges & 93.4 & - & - & 2.2 & 19.0 \\
\hline Collaboration of profit sharing & - & - & 85.4 & 317.9 & 317.8 \\
\hline (Gain) loss on fair value measurement & 30.5 & -38.9 & -0.5 & 27.2 & 36.1 \\
\hline Total Cost and Expenses & $5,872.8$ & $5,747.6$ & $4,441.7$ & $3,707.4$ & $3,324.0$ \\
\hline Gain on sale of rights & - & 16.8 & 24.9 & 46.8 & - \\
\hline Income from operations & $4,891.0$ & $3,972.5$ & $2,515.4$ & $1,855.9$ & $1,724.6$ \\
\hline Other income (expenses), net & -123.7 & -25.8 & -34.9 & -0.7 & -13.5 \\
\hline Income before income taxes & $4,767.3$ & $3,946.7$ & $2,480.5$ & $1,855.2$ & $1,711.1$ \\
\hline income tax expense & $1,161.6$ & 989.9 & 601.0 & 470.6 & 444.5 \\
\hline Equity in loss of investee, net of tax & 12.5 & 15.1 & 17.2 & 4.5 & - \\
\hline Net income & $3,593.2$ & $2,941.7$ & $1,862.3$ & $1,380.1$ & $1,266.6$ \\
\hline \multicolumn{6}{|l|}{ Supplemental information: } \\
\hline Interest Expense & 95.5 & 29.5 & 31.9 & 36.5 & 33 \\
\hline Weighted-average \# shares (WACS) & 230.7 & 236.4 & 236.9 & 237.9 & 242.4 \\
\hline
\end{tabular}

Table 1 includes the consolidated statement of income and supplemental data, collected from the company's annual $10 \mathrm{~K}$ reports for each year of the analysis. These reports can be found at https://www.biogen.com/en_us/ investors.html. 
Table 2. Biogen Inc. and Subsidiaries Consolidated Balance Sheets (in millions)

\begin{tabular}{|c|c|c|c|c|c|c|}
\hline & \multicolumn{6}{|c|}{ For the year ended December 31} \\
\hline & 2015 & 2014 & 2013 & 2012 & 2011 & 2010 \\
\hline \multicolumn{7}{|l|}{ Current assets } \\
\hline Cash \& cash equivalents & $1,308.0$ & $1,204.9$ & 602.6 & 570.7 & 514.5 & \\
\hline Marketable securities & $2,120.5$ & 640.5 & 620.2 & $1,135.0$ & $1,176.1$ & \\
\hline $\mathrm{A} / \mathrm{R}$, net & $1,227.0$ & $1,292.4$ & 824.4 & 686.8 & 584.6 & 605 \\
\hline Due from uncons. & 314.5 & 283.4 & 252.7 & 268.4 & 228.7 & \\
\hline Inventory & 893.4 & 804.0 & 659.0 & 447.4 & 326.8 & 289 \\
\hline Other current assets & 836.9 & 309.8 & 226.1 & 136.0 & 144.6 & \\
\hline Total current assets & $6,700.3$ & $4,535.0$ & $3,184.9$ & $3,244.3$ & $2,975.4$ & \\
\hline Marketable securities & $2,760.4$ & $1,470.7$ & 625.8 & $2,036.7$ & $1,416.7$ & \\
\hline PP\&E, net & $2,187.6$ & $1,765.7$ & $1,750.7$ & $1,742.2$ & $1,571.4$ & 1,642 \\
\hline Intangible assets, net & $4,085.1$ & $4,028.5$ & $4,474.7$ & $1,631.5$ & $1,608.2$ & 1,773 \\
\hline Goodwill & $2,663.8$ & $1,760.2$ & $1,232.9$ & $1,201.3$ & $1,146.3$ & 1,146 \\
\hline Investments and other assets & $1,107.6$ & 754.6 & 594.4 & 274.1 & 331.5 & \\
\hline Total assets & $19,504.8$ & $14,314.7$ & $11,863.3$ & $10,130.1$ & $9,049.6$ & 8,092 \\
\hline \multicolumn{7}{|l|}{ Current liabilities } \\
\hline Current portion of LTD & 4.8 & 3.1 & 3.5 & 453.4 & 3.3 & \\
\hline Taxes payable & 208.7 & 168.1 & 179.7 & 20.1 & 45.9 & \\
\hline Accounts payable & 267.4 & 229.2 & 219.9 & 204.0 & 186.4 & 163 \\
\hline Accrued exp. and other & $2,096.8$ & $1,817.7$ & $1,355.2$ & 979.9 & 677.2 & \\
\hline Total current liabilities & $2,577.7$ & $2,218.1$ & $1,758.3$ & $1,657.4$ & 912.9 & \\
\hline $\mathrm{N} / \mathrm{P}$ and other financing & $6,521.5$ & 580.3 & 592.4 & 687.4 & $1,060.8$ & \\
\hline Long-term def. taxes & 124.9 & 52.2 & 232.6 & 217.3 & 248.6 & \\
\hline Other long-term liabilities & 905.8 & 650.1 & 659.2 & 604.3 & 400.3 & \\
\hline Total long-term liabilities & $7,552.2$ & $1,282.6$ & $1,484.2$ & $1,508.9$ & $1,709.7$ & \\
\hline Total liabilities & $10,129.9$ & $3,500.7$ & $3,242.5$ & $3,166.3$ & $2,622.6$ & \\
\hline \multicolumn{7}{|l|}{ Equity } \\
\hline \multicolumn{7}{|l|}{ Biogen Inc. SHE } \\
\hline Common stock, par $\$ 0.0005$ & 0.1 & 0.1 & 0.1 & 0.1 & 0.1 & \\
\hline APIC & - & $4,196.2$ & $4,023.7$ & $3,854.5$ & $4,185.0$ & \\
\hline Accum. other comp loss & -224.0 & -59.5 & -27.7 & -55.3 & -26.5 & \\
\hline Retained Earnings & $12,208.4$ & $9,283.9$ & $6,349.1$ & $4,486.8$ & $3,106.8$ & \\
\hline Treasury stock, at cost & $-2,611.7$ & $-2,611.7$ & $-1,724.9$ & $-1,324.6$ & -839.9 & \\
\hline Total Biogen Equity & $9,372.8$ & $10,809.0$ & $8,620.2$ & $6,961.5$ & $6,425.5$ & \\
\hline Non-controlling interests & 2.1 & 5.0 & 0.6 & 2.3 & 1.5 & \\
\hline Total Equity & $9,374.9$ & $10,814.0$ & $8,620.8$ & $6,963.8$ & $6,427.0$ & 5,449 \\
\hline Total Liabilities \& Equity & $19,504.8$ & $14,314.7$ & $11,863.3$ & $10,130.1$ & $9,049.6$ & \\
\hline
\end{tabular}

Table 2 includes the consolidated balance sheets collected from the company's annual 10K reports for each year of the analysis. These reports can be found at https://www.biogen.com/en us/investors.html.

Table 3. Biogen Inc. and Subsidiaries Consolidated Statement of Cash Flows (Partial) (in millions)

\begin{tabular}{|l|r|r|r|r|r|r|}
\hline & \multicolumn{5}{|c|}{ For the years ended December 31 } \\
\hline & $\mathbf{2 0 1 5}$ & $\mathbf{2 0 1 4}$ & $\mathbf{2 0 1 3}$ & $\mathbf{2 0 1 2}$ & $\mathbf{2 0 1 1}$ \\
\hline Net Cash Flows Provided by Operations & $3,716.1$ & $2,942.1$ & $2,345.1$ & $1,879.9$ & $1,727.7$ \\
\hline Net Cash Flows Used in Investing Activities & $-4,553.6$ & $-1,543.0$ & $-1,604.7$ & -950.3 & $-1,650.3$ \\
\hline Net cash flows provided by financing activities & 986.4 & -755.9 & -716.5 & -877.5 & -319.9 \\
\hline Net increase in cash and cash equivalents & 148.9 & 643.2 & 23.9 & 52.1 & -242.4 \\
\hline Effect of exchange rate changes on cash & -45.8 & -40.9 & 8.0 & 4.1 & -2.6 \\
\hline Cash and cash equivalents, beg. of year & $1,204.9$ & 602.6 & 570.7 & 514.5 & 759.6 \\
\hline Cash and cash equivalents, end of year & $1,308.0$ & $1,204.9$ & 602.6 & 570.7 & 514.5 \\
\hline
\end{tabular}


Table 3 includes the consolidated statement of cash flows collected from the company's annual 10K reports for each year of the analysis. These reports can be found at https://www.biogen.com/en_us/investors.html.

Use Table 4 (below the requirements) for completing the analysis.

\section{REQUIREMENTS}

1. Calculate return on assets (ROA), using the Dupont Analysis approach. Use Table 4 (below) to develop your analysis. Discuss and interpret the overall trends in each component of the computation and in ROA for the five-year period with an emphasis on the 2014/15 periods. Calculate additional statistics to fully analyze trends (assess changes in percentage terms). Evaluate performance in terms of managerial decisions that impact ROA.

2. Calculate return on equity, ROE using the Dupont Analysis approach. Use Table 4 (below) to develop your analysis. Discuss and interpret the overall trends in the equity multiplier trend and in ROE for the five-year period with an emphasis on the 2014/15 periods. Calculate additional statistics to fully analyze trends. Evaluate performance in terms of managerial decisions that impact ROE. (It is not necessary to repeat your ROA analysis. Focus on addition of the equity multiplier and its impact on total ROE).

3. Provide a summary of your findings. Hint: Compare and contrast ROE during the time frame $2011-$ 2014 to the time frame 2014-2015. Discuss the change in operating and financing risk as a result of your analysis by examining ROE. (Operating risk relates to asset efficiency (asset turnover) and financing risk relates to the use of debt in the structure.)

4. Drill down into the ROA and ROE results by examining core operations and profitability, asset efficiency, and debt financing (see specific guidelines below).

\section{(1) OPERATIONS AND PROFITABILITY:}

Calculate the growth rate in TOTAL REVENUES for each year (See Table 4). Discuss the trends over time. Pay attention to the 2015 trend and tie it to stock performance in late 2015/2016.

Calculate gross profit margin. Discuss the trends over time. Has Biogen maintained its gross profit margin over the years? Discuss the relationship between sales growth and gross margins.

Calculate operating margin. Discuss the trends over time. Comment on significant changes that are driving the results. What evidence can you find in the case to support the trends in this ratio.

Calculate net profit margin and earnings per share. Discuss the trends over time. Comment on factors that are driving the trends.

As a measure of income quality, calculate net cash flow from operating activities to net income. Has Biogen improved the quality of its income (earnings) over time? What causes income quality to decline over time?

What core company value is required to maintain the levels of profitability earned by Biogen? Be sure to tie net income quality to your analysis and any other concerns you may have regarding these trends.

\section{(2) ASSET EFFICIENCY:}

Calculate A/R turnover, Days in Sales, Inventory Turnover, and Days in Inventory. Assess shortterm operating efficiency over the five-year period. What recommendations would you suggest to improve the short-term asset efficiency of operations? Be sure your recommendations relate to the impact that receivables and inventory have on the Dupont Analysis and specific managerial decisions that add value to the organization.

Calculate Intangible asset turnover, goodwill turnover, fixed asset turnover, net cash flow from operations to net cash flow used for investing activities and goodwill as a percentage of net 
income. Do you have any concerns or suggestions regarding long-term investments? Relate your suggestions to the impact on the Dupont Analysis.

(3) DEBT \& EQUITY FINANCING AND RISK:

Calculate the debt ratio, the debt-to-equity ratio, the long-term debt to equity ratio, and the timesinterest-earned ratio. Assess the five year trends and overall riskiness of the firm over time. Do you recommend any changes to the structure? Relate your suggestions to the impact on the Dupont Analysis. Address any trade-offs between risk and return that you believe are important.

(4) MARKET RATIOS: Obtain the daily stock price records of Biogen Inc. (BIIB ticker symbol) at www.Yahoo.com . Click on the Yahoo! Finance tab, type in the ticker symbol, and click on historical prices. Enter the range 12/31/11 - 12/31/15. Calculate the PE ratio. Assess the five-year trend. Given what you have learned, is the PE ratio in 2015 justified? Ignoring macro-economic and political variables, what company specific factors support the market's reaction to the stock price declining during the year (as discussed in the case).

(5) Re-examine the Dupont ROE in light of what you have learned. Summarize key recommendations regarding the three main areas of managerial decision making (operational, investing and financial aspects) for strengthening the company's ROE statistic.

Table 4. Biogen Inc. and Consolidated Subsidiaries Financial Statement Analysis

\begin{tabular}{|c|c|c|c|c|c|}
\hline Ratios & 2015 & 2014 & 2013 & 2012 & 2011 \\
\hline \multicolumn{6}{|l|}{ Questions 1 \& 2: } \\
\hline \multicolumn{6}{|l|}{ Dupont Analysis } \\
\hline \multicolumn{6}{|l|}{ Net Profit Margin (Net Income/Total Revenues) } \\
\hline \multicolumn{6}{|l|}{ Total Asset Turnover (Total Revenues/Average total assets) } \\
\hline \multicolumn{6}{|l|}{ Return on Assets $(\mathrm{ROA}=$ Net Profit Margin $\mathrm{x}$ Total Asset Turnover) } \\
\hline \multicolumn{6}{|l|}{ Equity Multiplier (Ave. Total Assets/Ave. Total Equity) } \\
\hline Return on Equity $(\mathrm{ROE}=\mathrm{ROA} \times$ Equity Multiplier) & & & & & \\
\hline
\end{tabular}

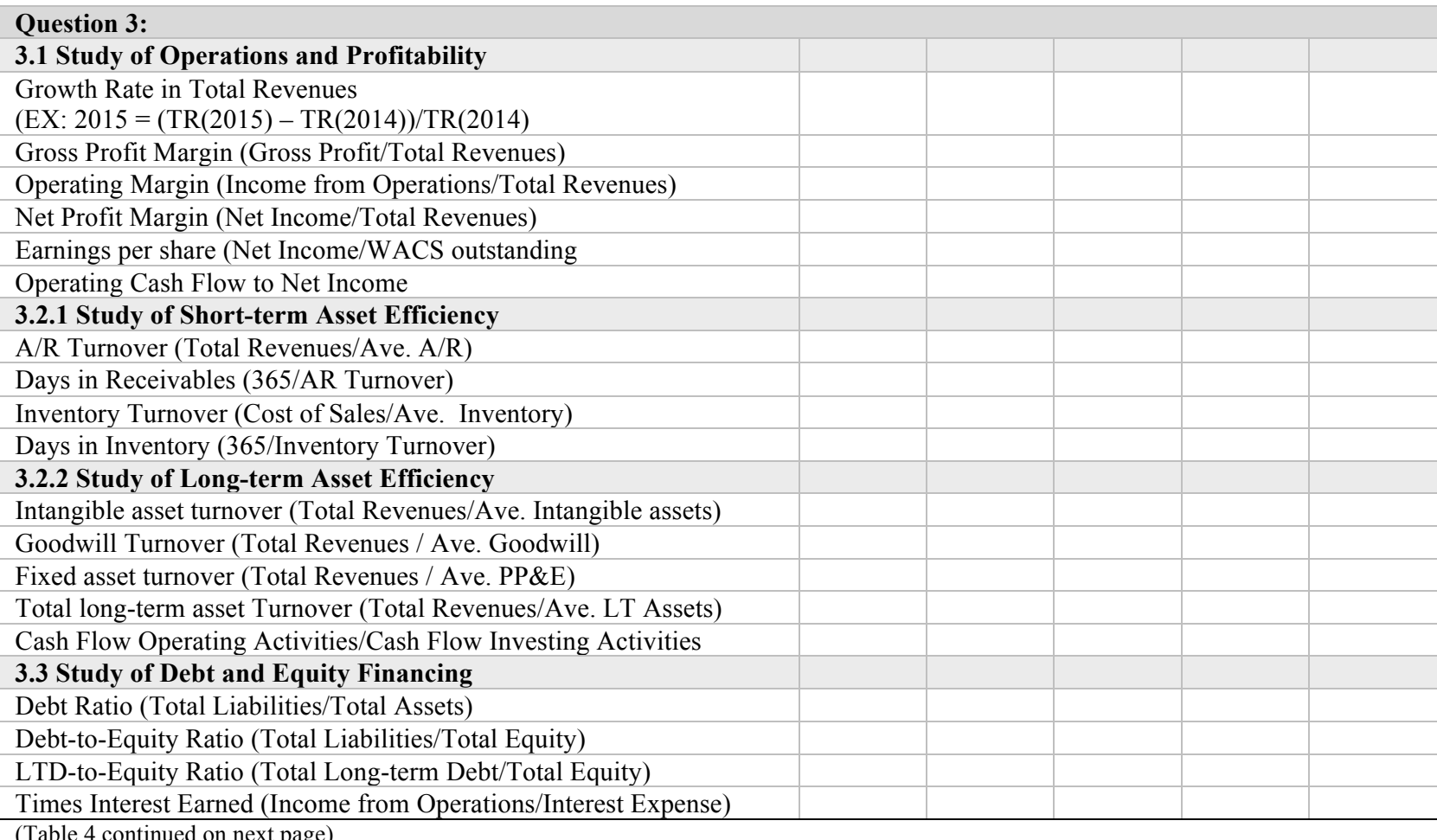

(Table 4 continued on next page) 
(Table 4 continued)

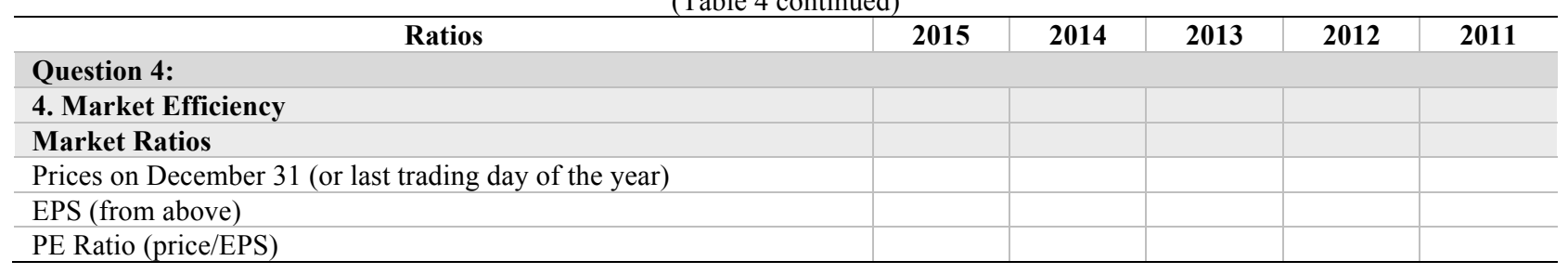

\section{RECOMMENDED SOLUTIONS}

\begin{tabular}{|c|c|c|c|c|c|}
\hline 1. Dupont Analysis ROA & \multicolumn{2}{l}{} \\
\hline Ratios & $\mathbf{2 0 1 5}$ & $\mathbf{2 0 1 4}$ & $\mathbf{2 0 1 3}$ & $\mathbf{2 0 1 2}$ & $\mathbf{2 0 1 1}$ \\
\hline Net Profit Margin & $33.4 \%$ & $30.3 \%$ & $26.9 \%$ & $25.0 \%$ & $25.1 \%$ \\
\hline Total Asset Turnover & 0.64 & 0.74 & 0.63 & 0.58 & 0.59 \\
\hline Return on Assets & $21.2 \%$ & $22.5 \%$ & $16.9 \%$ & $14.4 \%$ & $14.8 \%$ \\
\hline
\end{tabular}

Biogen's net profit margin ratio has increased 8.3 percentage points over the five-year period. From 2011 to 2014 total asset turnover increased 0.15 points, but then declined 0.10 points from 2014 to 2015 . Together, the resulting ROA statistic has increased 6.4 percentage points over the five-year period. However, ROA has declined from 2014 to 2015. This decline is attributed to a slowing in the amount of revenue generated for every dollar invested in assets.

\begin{tabular}{|c|c|c|c|c|c|} 
2. Dupont Analysis ROE & \multicolumn{1}{l}{} \\
\hline Ratios & $\mathbf{2 0 1 5}$ & $\mathbf{2 0 1 4}$ & $\mathbf{2 0 1 3}$ & $\mathbf{2 0 1 2}$ & $\mathbf{2 0 1 1}$ \\
\hline Return on Assets & $21.2 \%$ & $22.5 \%$ & $16.9 \%$ & $14.4 \%$ & $14.8 \%$ \\
\hline Equity Multiplier & 1.7 & 1.3 & 1.4 & 1.4 & 1.4 \\
\hline Return on Equity & $35.6 \%$ & $30.3 \%$ & $23.9 \%$ & $20.6 \%$ & $21.3 \%$ \\
\hline
\end{tabular}

As found in \#1, ROA increased significantly over the first four years and then fell from $22.5 \%$ to $21.2 \%$ in 2015 . Biogen's equity multiplier remained fairly stable from 2011 to 2014 . Then, from 2014 to 2015 it increased significantly from 1.3 to 1.7 . As a result, the Return on Equity ratio increased 14.3 percentage points over the fiveyear period, primarily resulting from strong ROA (until 2015). Further increases in ROE in 2015 were attributed to increasing leverage. In 2015, Biogen has increased the portion of debt financing in its structure.

Overall, ROE has increased over the five-year period. During the first four years, the increase was attributed to improving profit margins and improving asset efficiency. The use of leverage in the structure was stable and was not a contributing factor to changes in ROE. The trend from 2014 to 2015, however, provides an interesting contrast. Although net profit margin is still increasing, asset turnover efficiency has declined and the use of financial leverage has increased. Both operating risk and financing risk has increased.

\begin{tabular}{l|c|c|c|c|c|} 
3.1 Operating Aspects Related to Profitability \\
\hline
\end{tabular}


Sales have grown rapidly until 2015. This trend is most likely due to failed product pipelines and slowing growth of existing pipelines (information from articles referenced in case). This is probably one of the key reasons the stock price has fallen in 2015. Gross margin has held steady, even though sales growth has declined. Margins on existing sales are still strong. Operating margin increased significantly in 2015. This is most likely due to the corporate restructuring (i.e. layoffs and workforce reductions). Net profit margins and EPS continue to grow even though the quality of the earnings declined significantly. Perhaps the company is recording more sales accruals or extending terms of payment to customers to generate additional sales. Inventory build-up or other working capital issues may be impacting the quality of earnings result. Further analysis is necessary to determine why the quality of earnings has declined.

\begin{tabular}{|c|c|c|c|c|}
\hline & 2015 & 2014 & 2013 & 2012 \\
\hline A/R Turnover (Total Revenues/Ave. A/R) & 8.54 & 9.17 & 9.17 & 8.68 \\
\hline Days in Receivables (365/AR Turnover) & 43 & 40 & 40 & 42 \\
\hline Inventory Turnover (Cost of Sales/Ave. Inventory) & 1.46 & 1.60 & 1.55 & 1.41 \\
\hline Days in Inventory (365/Inventory Turnover) & 250 & 228 & 235 & 259 \\
\hline
\end{tabular}

$\mathrm{A} / \mathrm{R}$ turnover has declined over the period. This can happen as a result of two factors: 1) credit sales are booked and the collection cycle is slower than normal credit sales, or 2) collections from customers have slowed and Biogen has not been able to maintain a strong record of collections. Certainly, more information is needed to recommend a course of action. In general, Biogen should ensure they are recording sales in accordance with GAAP and booking legitimate accruals for sales on account. Given the issue of slowing sales, this trend would cause one to question to legitimacy of some of the sales on account. It may even flag a concern for those on the external auditing team.

The upward trend in Inventory turns has also reversed in 2015. Clearly, Biogen is struggling with its product pipeline and customer accounts. This will have a negative impact on ROA (and ROE) as asset build-up creates a drag on total asset turnover.

\begin{tabular}{|c|c|c|c|c|}
\hline & 2015 & 2014 & 2013 & 2012 \\
\hline Intangible asset turnover (Total Revenues / Ave. Intangible assets) & 2.65 & 2.28 & 2.27 & 3.41 \\
\hline Goodwill Turnover (Total Revenues / Ave. Goodwill) & 4.87 & 6.48 & 5.70 & 4.70 \\
\hline Fixed asset turnover (Total Revenues / Ave. PP\&E) & 5.45 & 5.52 & 3.97 & 3.33 \\
\hline \multicolumn{5}{|l|}{ Total Long-term Asset } \\
\hline Cash Flow Operating Activities / Cash Flow Investing Activities & 0.82 & 1.91 & 1.46 & 1.98 \\
\hline
\end{tabular}

Overall, Biogen's long-term asset efficiency has slowed as less revenue for every dollar invested in long-term assets is generated. This trend will also have a negative impact on ROA (and ROE) as asset build up creates a drag on total asset turnover. The CFOA/CFIA ratio has also declined significantly indicating that the amount of cash generated from operations is not keeping pace with investments in long-term assets.

\begin{tabular}{|c|c|c|c|c|c|}
\hline ( & 2015 & 2014 & 2013 & 2012 & 2011 \\
\hline $\begin{array}{l}\text { Debt Ratio (Total Liabilities/Total } \\
\text { Assets) }\end{array}$ & $51.9 \%$ & $24.5 \%$ & $27.3 \%$ & $31.3 \%$ & $29.0 \%$ \\
\hline $\begin{array}{l}\text { Debt-to-Equity Ratio (Total } \\
\text { Liabilities/Total Equity) }\end{array}$ & 1.08 & 0.32 & 0.38 & 0.45 & 0.41 \\
\hline $\begin{array}{l}\text { LTD-to-Equity Ratio (Total Long- } \\
\text { term Debt/Total Equity) }\end{array}$ & 0.81 & 0.12 & 0.17 & 0.22 & 0.27 \\
\hline $\begin{array}{l}\text { Times Interest Earned (Income } \\
\text { from Operations/Interest Expense) }\end{array}$ & $\$ 51.21$ & $\$ 134.66$ & $\$ 78.85$ & $\$ 50.85$ & $\$ 52.26$ \\
\hline
\end{tabular}


Biogen's debt ratio has increase substantially from 2014 to 2015 (more than doubled). Pat of this can be attributed to the recapitalization to purchase shares for executive compensation purposes. This was evident, when working with the equity multiplier in the ROE calculation, and is the primary reason for the increasing trends in ROE. LTD to Equity has increased substantially indicating that the type of debt impacting the company's capital structure is primarily long-term debt. Finally, the times-interest-earned ratio has plummeted. Biogen has less profitability available to cover its interest obligations. Biogen's equity investment is much riskier as a result of the change in the structure. In this example, the use of additional debt financing has not strengthened the firm.

4. Market Efficiency

\begin{tabular}{|c|c|c|c|c|c|}
\hline Market Ratios & 2015 & 2014 & 2013 & 2012 & 2011 \\
\hline Prices on December 31 (or last trading day of the year) & $\$ 306.35$ & $\$ 339.45$ & $\$ 279.57$ & $\$ 146.37$ & $\$ 110.05$ \\
\hline EPS (from above) & $\$ 15.58$ & $\$ 12.44$ & $\$ 7.86$ & $\$ 5.80$ & $\$ 5.23$ \\
\hline PE Ratio (price/EPS) & $\$ 19.67$ & $\$ 27.28$ & $\$ 35.56$ & $\$ 25.23$ & $\$ 21.06$ \\
\hline
\end{tabular}

As a result of decreasing sales, failed product pipelines, corporate restructuring, layoffs, and a doubling of debt in the capital structure, Biogen's stock price has decreased significantly. The declining PE ratio in 2015 reflects these struggles. Using the DUPONT analysis helps isolate the tools (profit/assets/debt) available to managers to improve the firm. Revenue generation and cost management strategies will continue to be major area of focus for the firm to ensure profitability remains strong. New product pipelines are critical to future success and resulting profit margins are key to maintaining ROA/ROE strength. Management should also carefully manage assets including receivables, inventory and long-term investments to ensure asset efficiency. Although the firm is still at safe levels of D/E, prudence is needed to avoid excessive risk taking. Biogen more than double the use of debt in the structure and this shift impacts future flexibility in financing choices. Overall, even though Biogen's ROE has increased, most of this is attributed to increasing levels of debt. Biogen's stock price may continue to lag until they show evidence of stronger revenue growth. 


\begin{tabular}{|c|c|c|c|c|}
\hline $\begin{array}{c}\text { BIOGEN CASE } \\
\text { GRADING RUBRIC }\end{array}$ & Failed to meet & Approaching & Meets Expectations & $\begin{array}{c}\text { Exceeds } \\
\text { Expectations }\end{array}$ \\
\hline Points & $\mathbf{0}$ & 1 & 2 & 3 \\
\hline $\begin{array}{l}\text { 1. Calculate ROA using } \\
\text { Dupont approach. } \\
\text { Discuss trends and } \\
\text { interpret results. Focus on } \\
2014 / 15 \text { change. }(5 \%)\end{array}$ & $\begin{array}{l}\text { Computes each ratio } \\
\text { correctly utilizing } \\
\text { Excel functions }\end{array}$ & $\begin{array}{l}\text { Assesses at least } \\
\text { two trends correctly }\end{array}$ & $\begin{array}{l}\text { Interprets performance } \\
\text { correctly; computes } \\
\text { additional statistics to } \\
\text { support interpretation }\end{array}$ & $\begin{array}{l}\text { Recognizes } \\
\text { managerial course of } \\
\text { action to achieve } \\
\text { result }\end{array}$ \\
\hline $\begin{array}{l}\text { 2. Calculate ROE using } \\
\text { Dupont approach. } \\
\text { Discuss trends and } \\
\text { interpret results. Focus on } \\
2014 / 15 \text { change. }(5 \%)\end{array}$ & $\begin{array}{l}\text { Computes each ratio } \\
\text { correctly utilizing } \\
\text { Excel functions }\end{array}$ & $\begin{array}{l}\text { Assesses trends } \\
\text { correctly }\end{array}$ & $\begin{array}{l}\text { Interprets performance } \\
\text { correctly; computes } \\
\text { additional statistics to } \\
\text { support interpretation }\end{array}$ & $\begin{array}{l}\text { Recognizes } \\
\text { managerial course of } \\
\text { action to achieve } \\
\text { result }\end{array}$ \\
\hline $\begin{array}{l}\text { 3. 1) Calculate growth rate } \\
\text { in revenues, gross profit } \\
\text { margin, operating margin, } \\
\text { net profit margin, EPS, } \\
\text { and income quality. } \\
\text { Discuss trends and } \\
\text { interpret results; Assess } \\
\text { income quality and } \\
\text { company culture. }(20 \%)\end{array}$ & $\begin{array}{l}\text { Computations are } \\
\text { correct; utilizes Excel } \\
\text { functions }\end{array}$ & $\begin{array}{l}\text { Assesses at least } \\
\text { two trends correctly }\end{array}$ & $\begin{array}{l}\text { Assesses trends } \\
\text { correctly; interprets } \\
\text { performance correctly; } \\
\text { computes additional } \\
\text { statistics to support } \\
\text { interpretation }\end{array}$ & $\begin{array}{l}\text { Recognizes } \\
\text { managerial course of } \\
\text { action to achieve } \\
\text { result; company } \\
\text { culture; nature of } \\
\text { accruals }\end{array}$ \\
\hline $\begin{array}{l}\text { 2)alculate A/R turnover, } \\
\text { days in sales, inventory } \\
\text { turnover, days in } \\
\text { inventory, intangible } \\
\text { turnover, goodwill } \\
\text { turnover, fixed asset } \\
\text { turnover, net } \\
\text { CFOA/CFIA. Assess } \\
\text { trends and interpret } \\
(20 \%)\end{array}$ & $\begin{array}{l}\text { Computations are } \\
\text { correct; utilizes Excel } \\
\text { functions }\end{array}$ & $\begin{array}{l}\text { isesses at least two } \\
\text { trends correctly }\end{array}$ & $\begin{array}{l}\text { Assesses all trends } \\
\text { correctly; interprets } \\
\text { performance correctly; } \\
\text { computes additional } \\
\text { statistics to support } \\
\text { interpretation }\end{array}$ & $\begin{array}{l}\text { Recognizes } \\
\text { managerial course of } \\
\text { action to achieve } \\
\text { result }\end{array}$ \\
\hline $\begin{array}{l}\text { 3) Calculate debt ratio, } \\
\text { debt-to-equity ratio, TIE } \\
\text { ratio. Assess and interpret } \\
\text { trends }(20 \%)\end{array}$ & $\begin{array}{l}\text { Computations are } \\
\text { correct; utilizes Excel } \\
\text { functions }\end{array}$ & $\begin{array}{l}\text { Assesses at least } \\
\text { two trends correctly }\end{array}$ & $\begin{array}{l}\text { Assesses all trends } \\
\text { correctly; interprets } \\
\text { performance correctly; } \\
\text { computes additional } \\
\text { statistics to support } \\
\text { interpretation }\end{array}$ & $\begin{array}{l}\text { Recognizes } \\
\text { managerial course of } \\
\text { action to achieve } \\
\text { result }\end{array}$ \\
\hline $\begin{array}{l}\text { 4. Obtain stock prices and } \\
\text { calculate PE ratio. Assess } \\
\text { and interpret trends }(20 \%)\end{array}$ & $\begin{array}{l}\text { Computations are } \\
\text { correct; utilizes Excel } \\
\text { functions }\end{array}$ & $\begin{array}{l}\text { Assesses trends } \\
\text { correctly }\end{array}$ & $\begin{array}{l}\text { Interprets performance } \\
\text { correctly; computes } \\
\text { additional statistics to } \\
\text { support interpretation }\end{array}$ & $\begin{array}{l}\text { Recognizes } \\
\text { managerial course of } \\
\text { action to achieve } \\
\text { result }\end{array}$ \\
\hline $\begin{array}{l}\text { 5. Summarize key } \\
\text { recommendations }(10 \%)\end{array}$ & Opinion only & $\begin{array}{l}\text { Answer is } \\
\text { supported by data; } \\
\text { provides some } \\
\text { rationale for } \\
\text { making effective } \\
\text { managerial } \\
\text { decisions }\end{array}$ & $\begin{array}{l}\text { Recommendations } \\
\text { integrate key domains } \\
\text { of managerial decision } \\
\text { making; long-range } \\
\text { considerations are } \\
\text { mentioned }\end{array}$ & $\begin{array}{l}\text { Recognizes systemic } \\
\text { risks; considers } \\
\text { market-based impacts } \\
\text { on future success }\end{array}$ \\
\hline \multicolumn{5}{|l|}{$\begin{array}{l}\text { BONUS: Format for ease of } \\
\text { grading and appropriate use } \\
\text { of Excel functions }(5 \%)\end{array}$} \\
\hline Total & & & & \\
\hline
\end{tabular}




\section{AUTHOR BIOGRAPHY}

Susan Wright is an Assistant Professor at the State University of New York at Oswego in the Accounting, Finance and Law Department. Email: susan.wright@oswego.edu

\section{REFERENCES}

Biogen, Inc. SEC Filings, 10K, 2015, 2014, 2013, 2012, and 2011 obtained online at https://www.biogen.com/en_us/investors.html

Company Press Release on November 11, 2015, "Steven Holtzman to Retire from Biogen" $\mathrm{http}: / /$ media.biogen.com/press-release/corporate/steven-holtzman-retire-biogen

Company Press Release on October 9, 2015, "Biogen Announces Departure of Tony Kingsley" $\mathrm{http} / /$ media.biogen.com/press-release/corporate/biogen-announces-departure-tony-kingsley

Company Press Release on September 11, 2015, "Biogen Prices \$6.0 Billion of Senior Unsecured Notes" http://media.biogen.com/press-release/investor-relations/biogen-prices-60-billion-senior-unsecured-notes

Tirrell, Meg, October 21, 2015, "Biogen Cuts 11\% of Workforce in Restructuring http://www.cnbc.com/2015/10/21/biogen-cuts-11-of-workforce-in-restructuring.html 